\title{
The Impact of Service Quality on Customer Satisfaction in Case of Selected Insurance Companies in Bale Robe Town
}

\author{
Biniam Getnet (MBA) \\ Bonga University, Department of Management
}

\begin{abstract}
The purpose of this study is to investigate impacts of service quality on customer satisfaction in selected insurance companies on Bale Robe Town. Since, service quality model was especially developed to examine the quality service of insurance; researchers selected this model to extensively test retail insurance industry. The current study measured service quality and its relation with customer satisfaction in the selected public and private branch. Exploratory method used as the research method of the study. The sample consists of 268 respondents' selected based on random sampling procedure. The dimensions of the study were tangibility, reliability, responsiveness, assurance and empathy.Primary data were collected by using 5-point Likert scale questionnaire and interview with customer service managers and customer service supervisors of the selected insurance companies. A total of 226 questionnaires were properly filled and returned. The empirical result shows that service quality dimensions; assurance, empathy and reliability have strong influence on user's satisfaction level respectively and weak impact with tangibility and responsiveness to user's satisfaction level in selected insurance companies in Bale Robe Town. Correlation and multiple regressions were used to investigate the relationship between dependent and independent variables. The correlation results indicate that there is a positive correlation between the dimensions of service quality and customer satisfaction. The results of the regression test showed that offering service quality have impact on overall customer satisfaction. The research proves that assurance, reliability and tangibility have strong influence on user's satisfaction level respectively and weak impact with empathy and responsiveness to user's satisfaction level in selected insurance companies in Bale Robe Town. Thus study concluded that service quality, if managed effectively, can contribute significantly towards customer satisfaction.
\end{abstract}

Keywords: Service quality, Customer Satisfaction, Insurance

DOI: $10.7176 / \mathrm{EJBM} / 12-31-01$

Publication date: November $30^{\text {th }} 2020$

\section{Introduction}

Service quality means the difference between the customer's expectation of service and their perception of perceived service. Zeithaml, et.al., (1990). By purchasing insurance policies, individual can receive reimbursement for losses due to car accidents, theft of property, and fire; medical expenses and loss of income due to disability or death (William, etal, 1998). Most companies are now beginning to use quality management programs in order to improve their performances, and that in turns leads to a customer satisfaction, Kotler et al, (2002). Insurance is one of the risk management techniques that provide protection against a financial loss arising from the occurrence of these unexpected events (Teklegiorgis Assefa, 2004)

Service quality is generally viewed as the output of the service delivery system, especially in the case of pure service system. Moreover, service quality leads to customer satisfaction. (Jain et al, 2009).

Ethiopian insurance companies consider delivery of excellent service quality to customer a key to success and survival, the finding from the study can provide them with the valuable insight in a way of enhancing service quality to induce greater customer satisfaction. The research was conducted at Ethiopian insurance corporation and United insurance company customers in Robe Town hence the study is to assess the impact of service quality on customer satisfaction in the case of selected insurance companies.

\section{Statement of Problem}

Delivering quality service to customers is a must for success and survival in today's competitive environment (Samli and Frohlich, 1992). Insurance Companies in Ethiopia are in a tough competition to attract customers by delivering various services. It is better for customers to have broad choices to select best Insurance Company for them to satisfy their needs. In pursuit of round the clock customer services and keep abreast with the developing global technology, some Insurance Companies in Ethiopia are fast moving toward launching new technology based products and services. Likewise, provision of high quality services enhances customer retention rates, helps attract new customers through word of mouth advertising, increases productivity, leads to higher market shares, lowers staff turnover and operating costs, and improves employee morale, financial performance and profitability, Julian and Ramaseshan, (1994); Lewis, (1989, 1993).

Insurance industries that excel in quality service can have a distinct marketing edge since an improved levels of service quality are related to higher revenues, increased cross- sell ratios, higher customer retention, Bennett and Higgins, (1988), and expanded market share, Bowen and Hedges, (1993). In a highly competitive and customer-centered market economy, service organizations are forced to provide high-quality services that generate 
customer satisfaction, loyalty, enlarge market share and improve their performance results (Pantouvakis, 2010). The application of customer relationship marketing is vital in today's fierce competition because when there are proper communication and smooth relationship with customers' organization should retain their customers (Kotler and Armstrong, 2010).

Service quality is an important tool to measure customer satisfaction (Hazlina et al., 2011). According to Jamal and Anastasiadou (2009), reliability, tangibility and empathy positively related with customer satisfaction. Sulieman (2011) found that reliability, tangibility, responsiveness and assurance have significant and positive relationship with customer satisfaction.

Because service quality has been proven to be the best determinant of customer satisfaction and indirectly customer loyalty when it comes to service sectors, Daniel et al (2012). Unsatisfactory service leads to a drop in customer satisfaction, loyalty and willingness to recommend the service to a friend. This would in turn lead to an increase the number of customers shifts to competitors. Therefore, the study is designed to examine the impact of service quality dimensions on customer satisfaction and to show service quality limitations on dimensions to fill the existing gap on service quality in case of selected insurance companies in Bale Robe Town.

\section{Research Hypothesis}

Providing high standard of service quality can result in high level of customer satisfaction (Suki \& Suki, 2013) and it five dimensions, including tangibility, reliability, responsiveness, assurance, and empathy, has been conceptualized the hypothesis of the research which aim to identify the relationship of those five dimensions with customer satisfaction construct (Zeithaml, et al., 1996).

The dimension tangibility of service quality model refers to appearance of physical facilities (Parasuraman, et al., 1988), and in the hostel context, it can include reception desk, cleanliness of premises in general, promotion documents and it factors are correlated to customer satisfaction (Lai, 2004; Kumar et al., 2010).

The dimension responsiveness refers to the willingness to help customers and to provide prompt service to meet the customers' needs (Parasuraman, et al., 1988) and it dimension is relate to the instant feedback and easy access (Polatoglu \& Ekin, 2001), and also is likely to have an important and positive effect on customer satisfaction (Glaveli et al., 2006; Mengi, 2009; Kheng et al., 2010).

The dimension assurance represents the knowledge and courtesy of employees and their ability to convey trust and confidence (Parasuraman, et al., 1988) being an important factor to the customers experiencing the service (Mengi, 2009) and can affects customer satisfaction (Kheng et al., 2010).

Proposed hypothesis are: Null Hypothesis

H01: Tangibility has no significant impact on Customer Satisfaction.

H02: Reliability has no significant impact on Customer Satisfaction.

H03: Responsiveness has no significant impact on Customer Satisfaction.

H04: Assurance has no significant impact on Customer Satisfaction.

H05: Empathy has no significant impact on Customer Satisfaction.

\section{Objectives of the Study \\ General Objective}

The main objective of this study is to find the impact of service quality dimensions on customer satisfaction in case of Selected Insurance Companies in Bale Robe Town.

\section{Specific Objectives}

Specific objectives of the study:

$>$ To identify the major service quality dimensions that have impact on customer satisfaction

$>$ To analyze the level of customer satisfaction on Service quality

$>$ To find out the problems in Service quality dimensions to satisfy the customers

\section{Research Design}

To gain understanding of the major impacts of service quality on the level of customer's satisfaction under different contexts of research methodology was conduct for this study. Based on empirical research across different industries, including pest control, fast food, dry cleaning, Insurance and bank, they provided evidences that support the distinction over SERVQUAL model based on performance only, maintained the same items scale proposed by Parasuraman et al. (1988). Moreover, as (Mark, Philip, \& Adrian, 2009) stated, case study methodology uses both explanatory and descriptive research design argues that multiple methods are useful for providing better opportunities to test hypothesis and also allows to the research findings can be trusted and inferences made from them. which was quantitatively analyze using multiple linear regression model and semi-structured interview and qualitatively analyze and triangulate with the quantitative result.

\section{Data Source \& Collection Method}

The study used primary data source include semi structured interview and questionnaire. A questionnaire was distributed to respondents who have service quality in the selected Robe Town insurance companies. The questionnaire was design based on previous empirical literature and its consistency was pre- test using Cronbach 
Alpha. The components of service quality dimensions and outcomes of customer satisfaction items was measured on 5- point Likert - scale ranging from 1 (strongly disagree) to 5 (strongly agree).

The research respondent was asking to indicate the degree of agreement or disagreement on service quality dimensions offering by their insurance companies. Some demographic questions were also forward. Every questionnaire is personally handing and an instruction was given to each customer before completing the questionnaire. Furthermore, for the semi structured interview, they were conduct for Operation Managers of selected insurance companies.

\section{Target Population}

The population of this study was customers from of the selected public and private insurance companies, which are Ethiopian Insurance Corporation and United Insurance Company active customers.

\section{Sampling Method and Sample Size}

The sampling method for the target population used simple random sampling. In random sampling, each individual in the population has an equal probability of selected which is important for the external validity of the study (Creswell, 2009).

Accordingly, the total study population 820 in the two insurance companies and Sample size of 268 respondents is taken from selected insurance companies. To calculate sample size, simplified formula provided by Taro Yamane (1967) is used i.e.

$$
\mathrm{n}=\mathrm{N} / 1+\mathrm{N}(\mathrm{e}) 2=\underline{\underline{\mathbf{2 6 8}}}
$$

\begin{tabular}{|c|c|c|c|}
\hline Insurance Name & Active number of Customers & Percentage of population & Sample Size \\
\hline EIC & 470 & 57.31 & 154 \\
\hline UIC & 350 & 42.69 & 114 \\
\hline
\end{tabular}

Table 1: Sample size from total population

\section{Reliability of the study}

Reliability refers to the degree to which a set of variables are consistent with what they are intended to measure (Hacker et al., 2003). Accordingly, the reliability of the study survey is dependent on the extent of respondents Satisfaction in using quality services. The Reliability of this research study was be categorized under five dimensions of service quality determinant factors, which was compute by Cronbach Alpha value using statistical package for social scientists (SPSS) version 23 software. According to Hair, et al., (2006), if $\alpha$ is greater than 0.7, it means that it has high reliability.

\section{Measurement and Scaling}

The aim of this study is to examine the impact of five service quality dimensions on customer satisfaction by insurance companies. The researcher was employee Multiple Linear Regression models to determine the significance level of the variables for the customer satisfaction.

Customer satisfaction $=\mathrm{f}$ (business service quality dimensions)

Basically, $\mathrm{CSEB}=\alpha+\beta 1 \mathrm{X} 1+\beta 2 \mathrm{X} 2+\beta 3 \mathrm{X} 3+\beta 4 \mathrm{X} 4+\beta 5 \mathrm{X} 5+\varepsilon$

Where, $\mathrm{CS}=$ Customer Satisfaction

$\mathrm{X} 1=$ Tangibility, $\mathrm{X} 2=$ Reliability, $\mathrm{X} 3$ = Assurance, $\mathrm{X} 4=$ Responsiveness, $\mathrm{X} 5=$ Empathy

Here $\alpha$ is constant and $\beta$ is coefficient of estimate and $\varepsilon$ is the error term. Customer satisfaction is dependent variable and $\mathrm{X} 1$ to $\mathrm{X} 5$ are independent variables.

\section{Method of Data Analysis}

In order to facilitate the interpretation, the finding of the study both quantitative and qualitative was use in analyzing with SPSS version 23. To analyze and present the data the statistical tools use for this study, namely descriptive analysis, correlation and multiple regression analysis.

The descriptive statistical results were present by tables, frequency distributions and percentages to give a condensed picture of the data. This was achieving through summary of statistics, which includes the means, mode and standard deviations values which are computed for each variable in this study. In this study Pearson's correlation coefficient was used to determine the relationships between service quality dimensions (Tangibility, Reliability, Responsiveness, Assurance and empathy) and customer satisfaction. Multiple regression analysis was use to investigate the impact of service quality dimensions (Tangibility, Reliability, Responsiveness, Assurance and empathy) on customer satisfaction. 


\section{Results and Discussion}

Descriptive Statistics of the Service Quality Dimensions Composite scores

Descriptive Statistics

\begin{tabular}{|l|r|r|r|}
\hline & $\mathrm{N}$ & \multicolumn{1}{|c|}{ Mean } & Std. Deviation \\
\hline TANGIBILITY & 226 & 3.1711 & .72093 \\
REALIBILITY & 226 & 3.1980 & .62832 \\
RESPONSIVINESS & 226 & 3.3606 & .71526 \\
ASSURANCE & 226 & 3.3274 & .67201 \\
EMPATHY & 226 & 2.3894 & .83329 \\
\hline
\end{tabular}

Table -2: Descriptive Statistics of the Service Quality Dimensions Composite scores

Responsiveness has the highest score of 3.3606 followed by assurance with a score of 3.3274 . The least important perception according to the finding on empathy with a score of 2.3894 is to do more on empathy. This indicates that there are weaknesses in Insurance provide 24 hours' services within a week, Insurance has employees who give customers individual attention, Language to service delivery is easy to understand and applications allows online insured service and payment.

The more composite scores are above average and less than the mean maximum score. The findings of the study indicate that currently the service providers are perceived by the customers to be offering under satisfied. Analysis of Customer satisfaction items

Descriptive Statistics

\begin{tabular}{|l|r|r|r|}
\hline & $\mathrm{N}$ & Mean & \multicolumn{1}{|c|}{ Std. Deviation } \\
\hline Say positive things about the insurance services to other people & 226 & 3.46 & .874 \\
Encourage friends and relatives to select insurance companies that have & 226 & 3.42 & .897 \\
Online service & & & .693 \\
Intend to continue doing with the insurance companies that have applications & 226 & 3.54 & .731 \\
\hline
\end{tabular}

Table -3: Analysis of Customer satisfaction items

According table above, say positive things about the insurance services to other people item of Customer satisfaction has mean score of 3.46. This indicates that most of the clients agree to say positive things about the insurance. Encourage friends and relatives to select insurance companies that have online service item of Customer satisfaction has mean score of 3.42. This indicates that most of the clients agree to encourage friends and relatives to select insurance companies that have applications. Intend to continue doing with the insurance companies that have applications item of Customer satisfaction has mean score of 3.54. This indicates that most of the clients agree to say to continue doing with the insurance companies that have applications. The item Have strong preference on your insurance company of Customer satisfaction has mean score of 3.60. This indicates that most of the clients agree to say strong preference on their insurance company.

\section{Inferential Findings}

Reliability and validity Test

\begin{tabular}{|l|l|l|}
\hline Constructs & Number of items & Cronbach's Alpha \\
\hline Tangibility & 3 & 0.863 \\
\hline Reliability & 4 & 0.723 \\
\hline Responsiveness & 4 & 0.811 \\
\hline Assurance & 5 & 0.840 \\
\hline Empathy & 4 & 0.942 \\
\hline Customer satisfaction & 4 & 0.762 \\
\hline
\end{tabular}

Table - 4: Reliability and Sample Characteristic

In this research were conducted the reliability test using the Cronbach's alpha in order to identify the consistency of the items in the data instrument. The use of the Cronbach's alpha has become common practice in empirical research when multiple-item measures are applied as data instrument (Tavakol \& Dennick, 2011).

The reliability coefficient applied in this research allowed to identify the stability, consistency and also enhance the accuracy of assessment of the data instrument used in this research and it coefficient varies between 0 and 1 (Tavakol \& Dennick, 2011), where Bryman \& Bell (2011) considered acceptable internal reliability when greater than 0.80 , and others authors considered as excellent internal reliability when the Cronbach's alpha is greater than 0.9 , good between 0.8 and 0.9 , acceptable between 0.7 and 0.8 , questionable between 0.6 and 0.7 , and the others results lower than 0.5 can be explained by a low number of items, poor inter-relatedness between items or heterogeneous constructs.

Analyzing the five constructs of service quality dimensions and the customer satisfaction based on reliability test show that all the constructs has presented good internal reliability. 


\section{Hypothesis Testing}

The following two tests were done to determine the correlations: -

- Person correlation

- Regression analysis

The Relation of Service Quality dimension on Customer Satisfaction

In this analysis the five dimensions' service quality were tested against customer satisfaction as the dependent variable. A Person correlation analysis was done to determine this relationship.

Person Correlation analysis (Overall service quality dimensions)

\begin{tabular}{|c|c|c|c|c|c|c|c|}
\hline \multicolumn{8}{|c|}{ Correlations } \\
\hline & & Tangibility & Realibility & Responsiviness & Assurance & Empathy & Cust Satisfaction \\
\hline \multirow[t]{2}{*}{ Tangibility } & $\begin{array}{l}\text { Pearson } \\
\text { Correlation }\end{array}$ & 1 & & & & & \\
\hline & Sig. (2-tailed) & & & & & & \\
\hline \multirow[t]{2}{*}{ Reliability } & $\begin{array}{l}\text { Pearson } \\
\text { Correlation }\end{array}$ & $.754^{* *}$ & 1 & & & & \\
\hline & Sig. (2-tailed) & .000 & & & & & \\
\hline \multirow[t]{2}{*}{ Responsiveness } & $\begin{array}{l}\text { Pearson } \\
\text { Correlation }\end{array}$ & $.688^{* *}$ & $.746^{* *}$ & 1 & & & \\
\hline & Sig. (2-tailed) & .000 & .000 & & & & \\
\hline \multirow[t]{2}{*}{ Assurance } & $\begin{array}{l}\text { Pearson } \\
\text { Correlation }\end{array}$ & $.722^{* *}$ & $.702^{* *}$ & $.711^{* *}$ & 1 & & \\
\hline & Sig. (2-tailed) & .000 & .000 & .000 & & & \\
\hline \multirow[t]{2}{*}{ Empathy } & $\begin{array}{l}\text { Pearson } \\
\text { Correlation }\end{array}$ & $.583^{* *}$ & $.608^{* *}$ & $.446^{* *}$ & $.401^{* *}$ & 1 & \\
\hline & Sig. (2-tailed) & .000 & .000 & .000 & .000 & & \\
\hline \multirow[t]{2}{*}{$\begin{array}{l}\text { Customer } \\
\text { Satisfaction }\end{array}$} & $\begin{array}{l}\text { Pearson } \\
\text { Correlation }\end{array}$ & $.642^{* * *}$ & $.638^{* *}$ & $.583^{* *}$ & $.786^{* *}$ & $.280^{* *}$ & 1 \\
\hline & Sig. (2-tailed) & .000 & .000 & .000 & .000 & .000 & \\
\hline
\end{tabular}

Table - 5: Person Correlation analysis on overall service quality dimensions on customer satisfaction

Correlation matrix is used in this study to show the strength of relationship among variables considered in the hypothesis. The correlation matrix further indicates that all service quality dimensions were positively correlated with customer satisfaction. The results indicate that most important service quality practice on customer satisfaction was Assurance (i.e. with highest scores of correlation), which goes to prove that assurance was perceived as a dominant service quality. The findings displayed that the respondent who perceived a greater awareness of service quality practice exhibited the more positive reactions in favor of customer satisfaction.

Multi linearity Test:

The correlation coefficient between the independent variable and dependent variable were less than 0.90 , indicating that data was not affected by a collinearly problem (Hair et al.,1998) and suggested that a correlation coefficient above 0.8 between explanatory variables should be corrected because it is a sign for multi linearity problem (Cooper \& Schindler, 2009). Therefore, as table 11 indicates that the correlation coefficient between explanatory variables have no collinear and multi linearity problem.

Linearity Test:

Linearity refers to the degree to which the change in the dependent variable is related to the change in the independent variables. To determine whether the relationship between the dependent variable CSEB and the independent variables X1 (Tangibility), X2 (Reliability), X3 (Responsiveness), X4 (Assurance) and X5 (Empathy) is linear plots of the regression residuals through SPSS version 23 software had been used. 


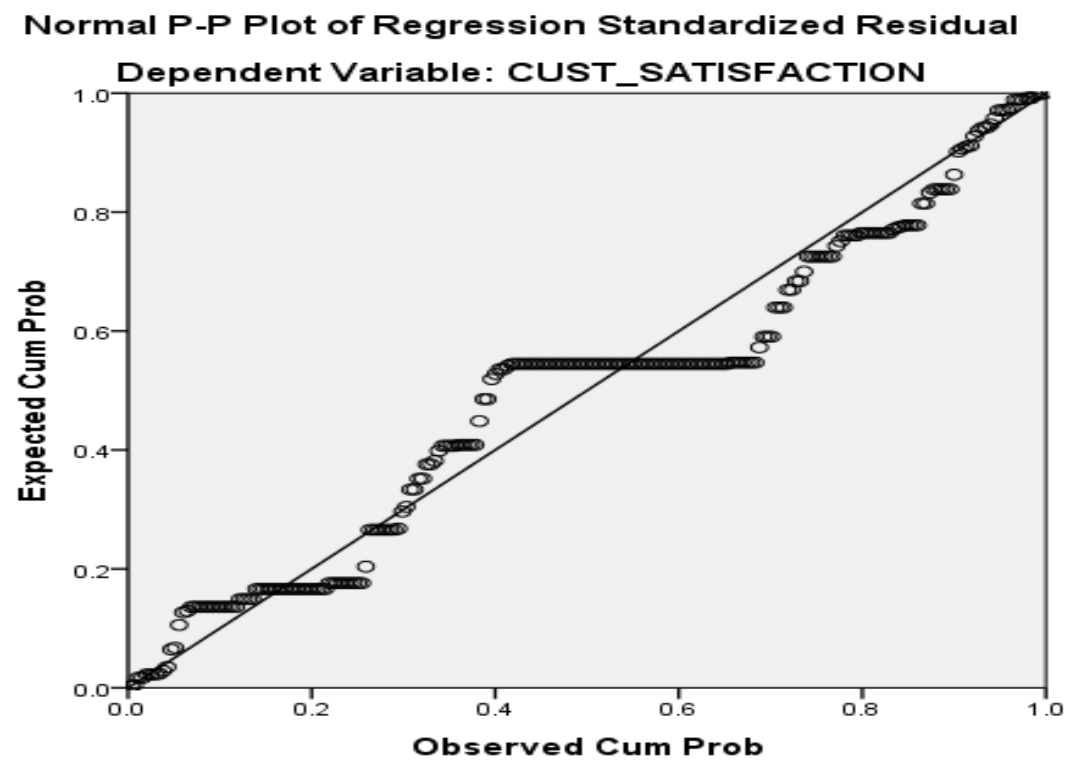

Figure- 1 : Normal Point Plot of Standardized Residual

The scatter plot of residuals shows no large difference in the spread of the residuals as you look from left to right on figure 1. This result suggests the relationship we are trying to predict is linear.

Normality Test:

As Per the Classical Linear Regression Models assumptions, the error term should be normally distributed or expected value of the errors terms should be zero $(E(u t)=0)$.

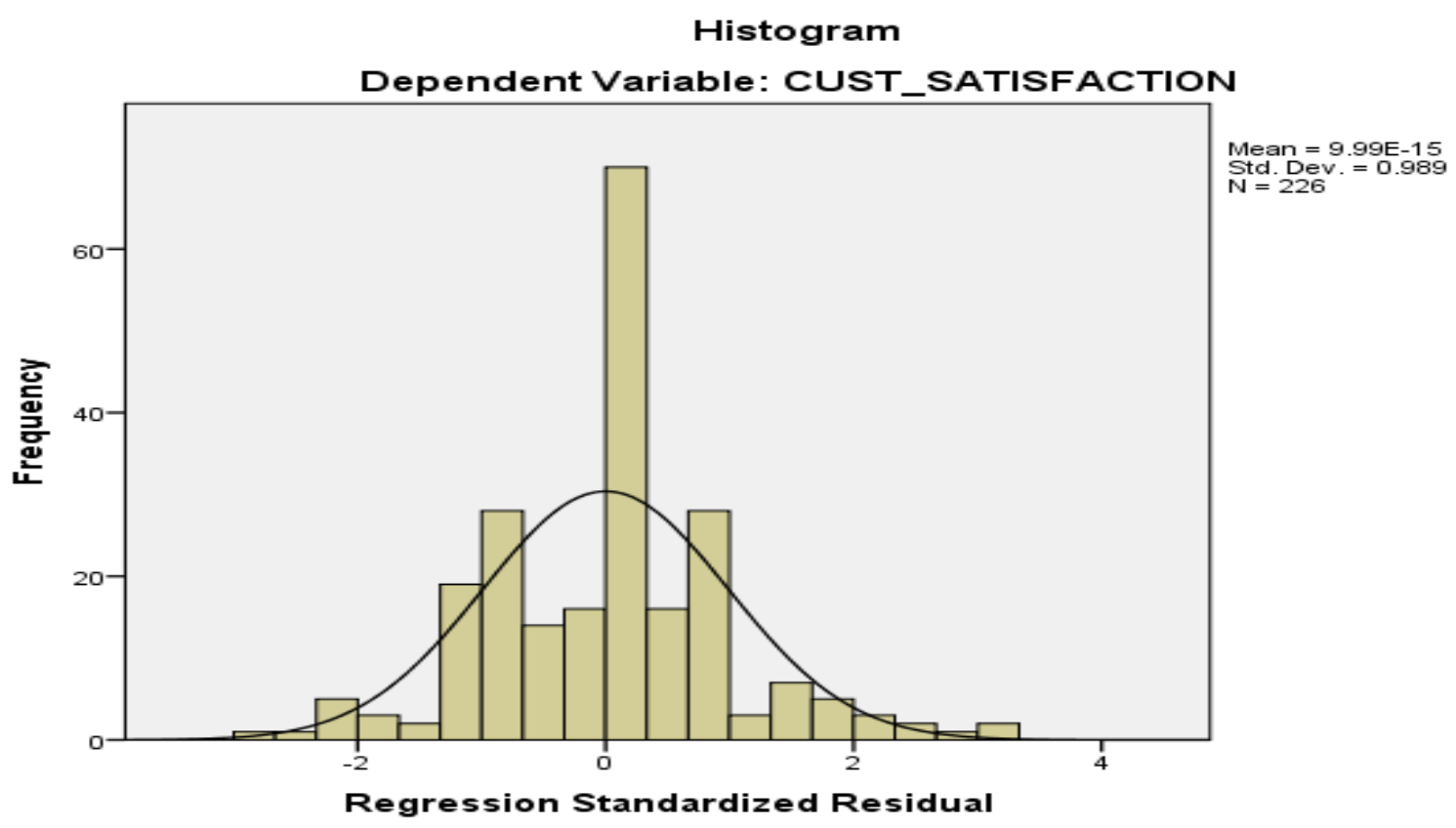

Figure- 2: Frequency Distribution of Standardized Residual

Frequency distribution of the standardized residuals compared to a normal distribution. As you can see, although there are some residuals (e.g., those occurring around 0 ) that are relatively far away from the curve, many of the residuals are fairly close. Moreover, the histogram is bell shaped which lead to infer that the residual (disturbance or errors) are normally distributed. Thus, no violations of the assumption normally distributed error term. Thus, from an examination of the information presented in all the three tests concluded that there are no significant data problems that would lead to say the assumptions of multiple regressions have been seriously violated.

\section{Multiple Regression Analysis}

In this part of the analysis includes a regression model to test the hypotheses. Five extracted dimensions were taken as independent variables against overall satisfaction of the customers as dependent variable in a multiple regression 
model. For all the hypotheses of the study below hypothesis test was used at 95\% confidence level.

Regression Summary of Service Quality to Customer Satisfaction (N=226)

\section{Model Summary}

\begin{tabular}{|c|c|c|c|c|c|c|c|c|c|}
\hline \multirow{2}{*}{ Model } & \multirow[t]{2}{*}{$\mathrm{R}$} & \multirow{2}{*}{ R Square } & \multirow{2}{*}{\begin{tabular}{|l|} 
Adjusted \\
R Square
\end{tabular}} & \multirow{2}{*}{$\begin{array}{l}\text { Std. Error of } \\
\text { the Estimate }\end{array}$} & \multicolumn{5}{|c|}{ Change Statistics } \\
\hline & & & & & R Square Change & Change & df1 & $\mathrm{df} 2$ & Sig. F Change \\
\hline & $.866^{\mathrm{a}}$ & .749 & .744 & 31103 & .749 & 131.464 & & 220 & .000 \\
\hline
\end{tabular}

Predictors: (Constant), EMPATHY, ASSURANCE, TANGIBILITY, RESPONSIVINESS, REALIBILITY

Dependent Variable: Customer satisfaction

Table - 6: Regression Summary of Service Quality to Customer Satisfaction

From table above, it has been seen that $R$ value is 0.866 . Therefore, $R$ value $(0.866)$ for the overall service quality dimensions suggested that there is a strong effect of these five independent variables on customer satisfaction. It can also have observed that the coefficient of determination i.e. the R-square value is 0.749 , which representing that $74.9 \%$ variation of the dependent variable (Average Customer Satisfaction) is due to the independent variables, which in fact, is a strong explanatory power of regression.

ANOVA ${ }^{\mathrm{a}}$

\begin{tabular}{|ll|r|r|r|r|r|}
\hline Model & Sum of Squares & df & Mean Square & F & Sig. \\
\hline \multirow{3}{*}{1} & Regression & 63.588 & 5 & 12.718 & 131.464 & $.000^{\mathrm{b}}$ \\
& Residual & 21.283 & 220 & .097 & & \\
& Total & 84.871 & 225 & & & \\
\hline
\end{tabular}

a. Dependent Variable: CUSTOMER SATISFACTION

b. Predictors: (Constant), EMPATHY, ASSURANCE, TANGIBILITY, RESPONSIVINESS, REALIBILITY

Table - 7: Anova Multiple regression presentation

From the table above-, it is identified that the value of F-stat is 131.464 and is significant as the level of significance is less than $5 \%(\mathrm{p}<0.05)$. This indicates that the overall model was reasonable fit and there was a statistically significant association between service quality dimension and customer satisfaction. Additionally, this also indicated that the null hypothesis is rejected or accepted.

\section{Coefficients}

\begin{tabular}{|c|c|c|c|c|c|c|c|}
\hline \multirow[t]{2}{*}{ Model } & \multicolumn{2}{|c|}{$\begin{array}{c}\text { Unstandardized } \\
\text { Coefficients }\end{array}$} & \multirow{2}{*}{\begin{tabular}{|c|}
$\begin{array}{c}\text { Standardized } \\
\text { Coefficients }\end{array}$ \\
Beta \\
\end{tabular}} & \multirow[t]{2}{*}{$\mathrm{T}$} & \multirow[t]{2}{*}{ Sig. } & \multicolumn{2}{|c|}{$95.0 \%$ Confidence Interval for B } \\
\hline & $\mathrm{B}$ & Std. Error & & & & Lower Bound & Upper Bound \\
\hline (Constant) & 1.056 & .111 & & 9.498 & .000 & .837 & 1.275 \\
\hline TANGIBILITY & .186 & .047 & .218 & 3.931 & .000 & .093 & .279 \\
\hline REALIBILITY & .325 & .146 & .332 & 2.225 & .027 & .037 & .613 \\
\hline RESPONSIVINESS & -.865 & .107 & -1.008 & -8.053 & .000 & -1.077 & -.654 \\
\hline ASSURANCE & 1.183 & .085 & 1.295 & 13.844 & .000 & 1.015 & 1.352 \\
\hline EMPATHY & -.087 & .039 & -.118 & -2.210 & .028 & -.165 & -.009 \\
\hline
\end{tabular}

a. Dependent Variable: CUSTOMER SATISFACTION

Table - 8: Coefficients of dependent varies with independent variable

In the table above, unstandardized coefficients indicated how much the dependent variable varies with an independent variable, when all other independent variables are held constant. The beta coefficients with significant $\mathrm{p}$ value $<0.05$ indicated that how and to what extent SERVQUAL dimensions such as tangibility, reliability, responsiveness, assurance and empathy influence customer's satisfaction of insurance companies. It has been found that, Assurance $(\beta=1.295, \mathrm{t}=13.844, \mathrm{p}<0.05)$, Reliability $(\beta=.332, \mathrm{t}=2.225, \mathrm{p}<0.05)$ and Tangibility $(\beta$ $=.218, \mathrm{t}=3.931, \mathrm{p}<0.05)$ have positive impact and significant on customer's satisfaction but Empathy $(\beta=-1.18$, $\mathrm{t}=-8.053, \mathrm{p}<0.05)$ and Responsiveness $(\beta=-1.008, \mathrm{t}=-8.053, \mathrm{p}<0.05)$ have negative impact and significant on customer's satisfaction.

\section{Conclusion and Recommendation \\ Conclusion}

The importance of measurement of service quality offered by companies has been recognized as one of the most important area of study for professionals of marketing with the purpose to understand the service quality performance from the customer perspective (Al Khattab \& Aldehayyat, 2011).

The main objective of this research was to identify the impact of the five dimensions of service quality, including tangibility, reliability, responsiveness, assurance and empathy, on customer satisfaction. The conceptual model proposed in this research states that service quality have a significant impact on customer satisfaction based on SERVQUAL model Parasuraman et al. (1988). 
Globally the results of the present research were supported by the conceptual model that the service quality has impact on customer satisfaction. The results from multiple linear regression also conducted that service quality can be used to predict customer satisfaction and based on all factors, P-value indicated that how and to what extent SERVQUAL dimensions such as tangibility, reliability, responsiveness, assurance and empathy influence customer's satisfaction on insurance companies. It has been found that, Assurance $(\beta=1.295, \mathrm{t}=13.844, \mathrm{p}<0.05)$, Reliability $(\beta=.332, \mathrm{t}=2.225, \mathrm{p}<0.05)$ and Tangibility $(\beta=.218, \mathrm{t}=3.931, \mathrm{p}<0.05)$ have positive impact and significant on customer's satisfaction but Empathy $(\beta=-1.18, \mathrm{t}=-8.053, \mathrm{p}<0.05)$ and Responsiveness $(\beta=-1.008$, $\mathrm{t}=-8.053, \mathrm{p}<0.05)$ have negative impact and significant on customer's satisfaction.

Thus, the service quality and customer satisfaction has been considered very important to help to improve the overall performance of business especially, for insurance industries. According by the literature review and the finding in this research is possible to state that the used to improve the services offered to customers with the purpose to reach the customer satisfaction and also build the competitive advantage against the competitors based on service differentiation.

\section{Recommendations}

Customer satisfaction is a critical business requirement. Customer value is an asset to the organization; While, application is essential in today's competitive market. The objective of this study was to find out customer satisfaction on service quality dimensions. A list of recommendations has been presented based on the findings of the research conducted on customers of selected insurance companies.

$>\quad$ The management needs to improve quality services so as to satisfy customer's needs. The insurance needs to pay much attention on the Tangibility, Reliability, Responsiveness, Assurance and Empathy in order to satisfy the customer's satisfaction by using different methods rather narrowly conceptualized in terms of five dimensions' service quality. Although $74.9 \%$ of the variation in customer's satisfaction was explained by the five service dimensions studied here, the remaining $25.1 \%$ is explained by other factors that were not examined in this study. For example, customer's satisfaction might be influenced by such factors as price, and service variety. It might be desirable for future studies to include these (and other) factors.

$>$ Insurance should work on integrating with bank to resolve in case of premium and other financial issues to save time and cost of customers by contacting branches.

$>$ Insurance companies should work with Ethio-Telecom \& Ethiopian Electric Power to resolve service interruptions and minimize the brunt of the consequences of unreliable services.

At last, this study investigates the dimensions of service quality that has major impacts on customer satisfaction on insurance industries in Ethiopia. But, the variables included in the study were not exhaustive variables which are not included under this study. Future researchers could include other variables which are not included under this study.

\section{References}

Antonio Coviello: The impact of ICT in the insurance industry: the role of Customer Relationship Management C.R. Kothari, 2004. Research Methodology: Method and Techniques. Available from Asubonteng P, McCleary KJ, Swan JE (1996). SERVQUAL revisited: a critical review of service quality. Journal of Service Marketing 6(6):62-81. Retrieved March10, 2013,

MGummesson, E., 1992, Quality Dimensions: What To Measure In Service Organization, Swartz,T.A. Bowen, marketing, Arizona State University.

Gummesson, E., 1993, Quality Management in Service Organizations, ISQA, Stockholm University, Sweden

Hatami GylgvHajan, Roqieh / development of e-commerce, marketing, the insurance industry, 2005.

Nikoofetrat, Bahman / benefits of e-commerce applications, 2007

HojatAhmadi and PeymanSalam (2009): Application of Information Systems in E-Insurance

Karanja Patricia Njambi (2004), Effects Of Internal Customer Satisfaction on Service Delivery In Resolution Insurance

Leila Meshkat (2012), Electronic Insurance and its application in e-commerce in Ghana

Lui, C., \& Arnett, K. (2000). Exploring the Factors Associated with Web Site Success in The context of Electronic Commerce

Parasuraman et al., (1988), SERVQUAL: A Multiple-Item Scale for Measuring Consumer Perceptions of Service Quality.

Suki \& Suki, (2013), Multiple-Item Scale for Measuring Consumer satisfaction on Service Quality

Taro Yemane (1967), determination of sample size

Svensson, G. (2006): The interactive interface of service quality - A conceptual framework,

European Business Review, vol.18, no.3, pp. 243-257

Yang, Z., Jun, M. \& Peterson, R. (2004), Measuring Customer Perceived Online Service Quality

Zeithaml, et al., (2006), Service Quality Delivery through Web Site: A Critical Review of Extant Knowledge. 